\title{
BARRIERS AND BENEFITS OF ADOPTING ELECTRONIC HEALTH RECORDS (EHRs) IN PUBLIC HOSPITALS
}

\section{BARIERY I KORZYŚCI ZWIĄZANE Z WPROWADZENIEM ELEKTRONICZNEJ DOKUMENTACJI MEDYCZNEJ (EDM) W PUBLICZNYCH SZPITALACH}

\author{
Deldar Morad Abdulah ${ }^{1(\mathrm{~A}, \mathrm{C}, \mathrm{E}, \mathrm{F})}$, Karwan Ali Perot ${ }^{2(\mathrm{~B}, \mathrm{C}, \mathrm{D}, \mathrm{F})}$ \\ ${ }^{1}$ Community and Maternity Health Nursing Unit, College of Nursing, University of Duhok, Iraqi Kurdistan \\ ${ }^{2} \mathrm{PhD}$ Candidate, School of Health and Environmental Sciences, Department of Public Health, \\ Auckland University of Technology, New Zealand
}

Authors' contribution Wkład autorów: A. Study design/planning zaplanowanie badań B. Data collection/entry zebranie danych C. Data analysis/statistics dane - analiza i statystyki D. Data interpretation interpretacja danych E. Preparation of manuscript przygotowanie artykułu F. Literature analysis/search wyszukiwanie i analiza literatury G. Funds collection zebranie funduszy

\section{Summary}

Background. Physicians make up the primary frontline healthcare practitioner group that must be engaged in the implementation of electronic health records (EHRs). This study aimed to explore physician attitudes and readiness towards the implementation of EHR systems in public hospitals. Material and methods. A total of 296 clinicians from four public hospitals in Iraqi Kurdistan with different job titles were included in the study.

Results. The physicians reported that top hospital management would give importance to the EHR project $(87.5 \%)$, include physicians in its implementation $(69.6 \%)$ and provide adequate training (69.75\%). EHRs may negatively affect physician attitudes due to increased control/monitoring of clinical practices by hospital administration (55.4\%) or due to security, legal, and ethical concerns (50.0\%), which may limit physician autonomy (51.8\%). Moreover, physicians reported that EHR may diminish patient confidence in physicians $(37.5 \%)$, may threaten physician credibility with patients (51.8\%), and will likely interfere with doctor-patient interactions $(55.4 \%)$. The analysis showed that autonomy could be limited due to the interference of EHRs in doctor-patient interactions $(p=0.003)$. Physician concerns with respect to patient relationships included privacy concerns $(p=0.008)$ and compromised physician autonomy $(p=0.003)$.

Conclusions. The physicians reported that while hospital management would support the implementation of an EHR system, the physicians had concerns about physician autonomy and potential negative impacts on doctor-patient relationships.

Keywords: physician acceptance, medical record systems, electronic health records, attitude

\section{Streszczenie}

Wprowadzenie. Lekarze są główną grupą służby zdrowia, która musi być zaangażowana we wdrażanie elektronicznej dokumentacji medycznej (EDM). Celem niniejszej pracy było zbadanie postaw i gotowości lekarzy do wdrożenia EDM w szpitalach publicznych.

Materiał i metody. W badaniu wzięło udział 296 lekarzy z czterech szpitali publicznych w irackim Kurdystanie, o różnej hierarchii zawodowej.

Wyniki. Lekarze deklarowali, że najwyższe kierownictwo szpitala przywiązałoby wagę do projektu $\operatorname{EDM}(87,5 \%)$, zaangażowałoby lekarzy w jego wdrożenie $(69,6 \%)$ oraz zapewniłoby im odpowiednie szkolenia $(69,75 \%)$. EDM może negatywnie wpływać na postawy lekarzy z powodu zwiększonej kontroli/monitoringu praktyk klinicznych przez administrację szpitala $(55,4 \%)$ lub z powodu obaw zwiazanych z bezpieczeństwem, prawem i etyką $(50,0 \%)$, co może ograniczać autonomię lekarzy $(51,8 \%)$. Ponadto lekarze stwierdzili, że EDM może zmniejszyć zaufanie pacjentów do lekarzy $(37,5 \%)$, może zagrozić wiarygodności lekarzy wobec pacjentów $(51,8 \%)$, a także prawdopodobnie zakłóci relację pomiędzy lekarzem a pacjentem $(55,4 \%)$. Analiza wykazała, że autonomia lekarzy będzie ograniczona $\mathrm{z}$ powodu ingerencji EDM w relację pomiędzy lekarzem a pacjentem $(p=0,003)$. Niepokój lekarzy dotyczący ich relacji z pacjentami wynikał z obawy o zagrożenie prywatności $(p=0,008)$ i ograniczenie autonomii lekarzy $(p=0,003)$.

Wnioski. Lekarze deklarowali, że pomimo, iż kierownictwo szpitala poparłoby wdrożenie systemu EDM, mają oni obawy dotyczące ich autonomii i potencjalnego negatywnego wpływu na relacje pomiędzy lekarzem a pacjentem.

Słowa kluczowe: akceptacja lekarzy, systemy dokumentacji medycznej, elektroniczna dokumentacja medyczna, postawa
Tables: 6

Figures: 1

Submitted: 2021 Dec 12

Accepted: 2022 Jan 31

Abdulah DM, Perot KA. Barriers and benefits of adopting electronic health records (EHRs) in public hospitals. Health Prob Civil. 2022; 16(1): 93-107. https://doi.org/10.5114/hpc.2022.113596

Address for correspondence / Adres korespondencyjny: Deldar Morad Abdulah, Community and Maternity Health Nurs Duhok, Nakhoshkhana Street, 42001 Duhok, Iraqi Kurdistan, e-mail: deldarmorad@gmail.com, phone: +9647507443319

ORCID: Deldar Morad Abdulah https://orcid.org/0000-0002-8986-5793, Karwan Ali Perot https://orcid.org/0000-0002-5012-2095

Copyright: (C) John Paul II University of Applied Sciences in Biala Podlaska, Deldar Morad Abdulah, Karwan Ali Perot. This is an Open Access journal, all articles are distributed under the terms of the Creative Commons Attribution-NonCommercial-ShareAlike 4.0 International (CC BY-NC-SA 4.0) License (http://creativecommons. org/licenses/by-nc-sa/4.0/), allowing third parties to copy and redistribute the material in any medium or format and to remix, transform, and build upon the material, provided the original work is properly cited and states its license. 


\section{Introduction}

Electronic health record (EHR) systems assist clinicians in accessing legible and organized medical records of patients across geographic locations. Information technology can help establish a health system that provides more effective methods for communicating and sharing information among physicians, better management of patient records, and reducing medical errors [1,2].

The Institute of Medicine (IOM) suggests the adoption of EHR to improve patient safety and the quality of healthcare [3]. Physicians have a central role in the successful adoption and implementation of an EHR system because they are key persons in recording patient information [4]. Continuous use of EHRs has been shown to be associated with a reduction in costs, an improvement in work effectiveness [5] and better patient outcomes [6].

Healthcare providers have been moving slowly to adopt EHRs despite broad agreement on its benefits [7]. Adler-Milstein et al. [8] reported that $80.5 \%$ of hospitals in the US have adopted at least a basic EHR system, which reflects a 5.4\% increase since 2014. The implementation of EHRs can be met with resistance from healthcare professionals that may be used to traditional paper systems [9].

Miller et al. [10] demonstrated that quality improvement is heavily driven by physicians' use of electronic systems for the majority of their daily tasks. However, physicians can perceive EHRs to negatively impact patient interactions [11], apart from complications they can introduce in clinical tasks [12]. Park et al. observed the operations of an emergency department (ED) prior to, during, and after a paper-to-electronic transition for six months [13]. The authors reported that the system had direct influences on documentation processes among ED doctors, including a four- to five-fold increase in documentation times, which resulted in an increase in incomplete charts, placing more documentation responsibilities on residents, and using paper notes to aid documentation. EHRs also led to indirect impacts, including an increased cognitive burden on physicians, increased interruptions, and it also caused doctors to become more stationery at their computers, which led to a reduction in time with patients [10].

Physician non-readiness towards EHR adoption is a barrier that hospital organizations face with respect to weak adoption and implementation [14]. Physicians are the main frontline group driving implementation and having their support has a great impact on other medical user groups in healthcare settings [15].

Implementation of EHRs in hospitals is a complex matter in which a wide range of organizational and technical factors play a role. Factors contributing to EHR implementation include human skills, organizational structure and culture, financial resources, technical infrastructure, and coordination $[3,16]$. The adoption of information systems in hospitals is considered to be more challenging compared to other settings owing to medical data complexity, data entry issues, limited recognition of the advantages of EHRs, and security and confidentiality concerns [17].

The importance of this study comes from the necessity of adopting health information systems in public hospitals in Iraqi Kurdistan. Use of EHRs is lagging in this region, and engaging physicians is key to a successful path of implementation. Bates et al. [18] and Harris-Salamone et al. [19] identified physician resistance as an important barrier to the acceptance of EHRs. Perceived barriers from the perspective of physicians could lead to the delay or failure in EHR implementation [20].

This study aimed to examine the readiness of clinicians to adopt EHR systems in the public health sector in the Kurdistan region of Iraq and determine reasons for physician resistance. The study does not claim that doctor resistance is the only reason for the non-adoption of EHRs in the hospitals. Health care providers in Iraqi Kurdistan have deep concerns about the inappropriate use of information technology for clinical and administrative-based tasks in healthcare settings [21]. Currently, to the authors' knowledge, Iraqi and Iraqi Kurdistan governments have not planned to develop information technology for patient medical records or other administrative affairs except for email for some administration affairs. This study aimed to examine and evaluate physician attitudes, readiness, and barriers as predictors in the implementation of EHRs in public hospitals in Iraqi Kurdistan.

\section{Material and methods}

\section{Study design and sampling}

In this cross-sectional study, four of the total eight available public hospitals in Erbil city in the Kurdistan region of Iraq were selected purposively for the study following official permission and from a list of hospitals from the General Directorate of Health - Erbil. The authors attempted to select hospitals with different 
specialties, including a multi-specialty hospital for adult populations, a pediatric hospital, an emergency hospital, and a surgical specialty hospital.

Clinicians who had direct patient care responsibilities and were available during data collection were invited personally and purposively to participate after obtaining verbal consent from each hospital. In this regard, 296 out of a total of 506 physicians who were invited accepted to participate in the study (response rate: $58.50 \%$ ). Physicians who did not have adequate time did not complete the questionnaire. The physicians were invited to the study irrespective of age, education level, socio-demographic factors, working shifts or sectors, or medical specialty. The study objectives were presented and information about EHRs was shared with the clinicians before beginning the study. Data was collected between February 13, 2018 to May 24, 2018.

The physicians who agreed to devote 20 minutes of their time to fill the questionnaire were invited to participate in the study. Participation in the study was entirely optional. The clinicians were guaranteed confidentiality regarding their personal information.

\section{Data collection and measurement criteria}

Data in the study were collected through self-reported questionnaires. The questionnaires were given directly to the physicians to complete. The author of the study visited the selected hospitals to invite the physicians to participate in the study. The author visited relevant clinical departments to recruit as many physicians as possible into the study. The demographic information that was collected from participants included age, gender, and working sector (public/private/both public and private sectors). Working shifts were determined according to the local health system and included morning shift: 8 am-2 pm; evening shift: 2 pm- 8 pm; and night shift 8 pm-8 am. Job titles as per the national health system included junior house officer, senior house officer, general practitioner, specialist, and consultant.

The questionnaire used in the study was developed and validated by Morton [22] specifically for examining physician attitudes towards EHR implementation and adoption. The scale has eight indicators rated on a 5-point Likert scale that ranges from strongly disagree to strongly agree: $1=$ strongly disagree, $2=$ agree, $3=$ neither agree/disagree, $4=$ agree, $5=$ strongly agree [23]. The means of the items are averaged to obtain the overall score for each sub-scale (Figure 1). 


\begin{tabular}{|c|c|}
\hline Dimensions & Description of Item \\
\hline Management Support & $\begin{array}{l}\text { included } \\
\text { 1) EHR project is important to top management; } \\
\text { 2) EHR project will be introduced to me effectively; } \\
\text { 3) Management will do an effective job during EHR implementation; } \\
\text { 4) Management will involve me in EHR implementation; } \\
\text { 5) Management will provide training that I need to use EHR effectively; } \\
\text { 6) I will have easy access to resources to help me use EHR; } \\
\text { 7) Management expects me to use EHR. }\end{array}$ \\
\hline Physician Involvement & $\begin{array}{l}\text { included } \\
\text { 1) My involvement during EHR implementation is a must; } \\
\text { 2) My involvement during EHR implementation will be effective; } \\
\text { 3) My involvement during EHR implementation will make EHR more useful to me; } \\
\text { 4) My involvement during implementation will make EHR easier to be used; } \\
\text { 5) Overall, my involvement will positively affect my attitude. }\end{array}$ \\
\hline Adequate Training & $\begin{array}{l}\text { included } \\
\text { 1) Training will be adequate; } \\
\text { 2) I will receive the training I need to understand/use EHR; } \\
\text { 3) Training will make EHR more useful to me; } \\
\text { 4) Training will make EHR easier for me to use. }\end{array}$ \\
\hline Physician Autonomy & $\begin{array}{l}\text { included: } \\
\text { 1) EHR will increase hospital administration's control; } \\
\text { 2) EHR will increase my hospital ability to control/monitor the physician's clinical } \\
\text { practices; } \\
\text { 3) EHR may threaten the physician's privacy; } \\
\text { 4) EHR may result in legal/ethical problems for the physician; } \\
\text { 5) EHR may limit the physician's autonomy; } \\
\text { 6) Overall, EHR may negatively affect a physician's attitude due to increased } \\
\text { control/monitoring of clinical practices; } \\
\text { 7) Overall, EHR may negatively affect a physician's attitude due to security, legal, ethical } \\
\text { concerns (Items of physician autonomy were presented from a negative perspective). }\end{array}$ \\
\hline $\begin{array}{l}\text { Doctor-Patient } \\
\text { Relationship }\end{array}$ & $\begin{array}{l}\text { included } \\
\text { 1) EHR may diminish the patient's confidence in a physician; } \\
\text { 2) EHR may threaten a physician's credibility with patients; } \\
\text { 3) EHR will likely decrease patient satisfaction; } \\
\text { 4) Overall, EHR will likely interfere with doctor-patient interaction (Items of the doctor- } \\
\text { patient relationship were presented from a negative perspective). }\end{array}$ \\
\hline Perceived Ease of Use & $\begin{array}{l}\text { included } \\
\text { 1) My interaction with EHR will be user-friendly; } \\
\text { 2) Learning to use EHR will be easier for me; } \\
\text { 3) I expect to become skilled using EHR; } \\
\text { 4) Overall, I expect EHR will be easy for physicians to use. }\end{array}$ \\
\hline Perceived Usefulness & $\begin{array}{l}\text { included } \\
\text { 1) EHR will improve the quality of my work; } \\
\text { 2) EHR will give me greater control over my work schedule; } \\
\text { 3) EHR will allow me to accomplish tasks more quickly; } \\
\text { 4) EHR will allow me to accomplish more work; } \\
\text { 5) EHR will enhance my overall effectiveness in my job; } \\
\text { 6) EHR will make my job easier to perform; } \\
\text { 7) Overall, EHR should be a useful tool for practicing. }\end{array}$ \\
\hline $\begin{array}{l}\text { Attitude About EHR } \\
\text { Usage }\end{array}$ & $\begin{array}{l}\text { included: } \\
\text { 1) EHR will support physicians in providing better care; } \\
\text { 2) I will encourage EHR among my colleagues; } \\
\text { 3) I need the EHR to provide effective patient care; } \\
\text { 4) I am not satisfied with using paper-based patient records; } \\
\text { 5) All physicians should learn to use the EHR effectively; } \\
\text { 6) Overall, my attitude about EHR usage will be positive. }\end{array}$ \\
\hline
\end{tabular}

Figure 1. Dimensions of the electronic health records questionnaire [22] 
Eight items across 296 questionnaires were not answered. These missing data were replaced by a mean of the sub-scales according to Morton [22]. The questionnaire was administered in its original language (English) as the physicians did not have any issue with English reading and comprehension. The positive and negative attitudes of physicians regarding EHR implementation were considered as benefits and barriers, respectively.

The questions were designed based on the Technology Acceptance Model (TAM), which was developed by Fred Davis in 1989 to establish a means to predict acceptance and discretionary use of information systems and technologies [24,25]. The TAM is based on Fishbein and Ajzen's theory of reasoned action (TRA). The TRA hypothesizes that a person's attitudes towards a particular behavior are recognized through their beliefs $[26,27]$. The TAM combines beliefs specific to technology adoption and generalizes to various computer systems and users $[24,25]$. It is a widely validated approach for predicting user acceptance of information systems. The tool is an approach that consistently produces reliable results over time $[28,29]$. This model allows investigators not only to predict but also describe the reasons for a lack of acceptance of the information system by users [25]. The TAM is considered a beneficial method in determining pre-implementation attitudes towards information systems in environments where system use is discretionary rather than mandated.

\section{Statistical analysis}

The descriptive purposes of the study were presented as frequency and percentage for categorical variables, and mean and standard deviation for continuous characteristics. Age was presented in mean and standard deviation and working sector, working shifts, and job levels in number and percentage. Physician attitudes towards adopting or implementing EHR were presented as means with standard deviation.

The difference in clinician attitudes based on job title was examined using one-way ANOVA. The predictors of barriers, including physician autonomy and the doctor-patient relationship, were examined using linear regression. In the linear regression model, physician autonomy was considered the outcome and management support, physician involvement, adequate training, doctor-patient relationship, perceived ease of use, perceived usefulness, attitude about usage, physician age, gender, education, working sectors, and working shift were the independent variables. Items pertaining to the doctor-patient relationship were added to the independent variables in the next step of linear regression for analyzing physician autonomy. In the second linear regression analysis, doctor-patient relationship related items were included as dependent variables while management support, physician involvement, adequate training, physician autonomy, perceived ease of use, perceived usefulness, attitude about usage, physician age, gender, education, working sectors, and working shift were independent items. Physician autonomy items were added to the independent items in the second step of the linear regression analysis.

The overall Cronbach's alpha of 0.922 measured in the study included management support (0.803), physician involvement (0.603), adequate training (0.724), physician autonomy (0.717), doctor-patient relationship (0.857), perceived ease of use (0.763), perceived usefulness (0.879), and attitude about EHR usage (0.719). The null hypothesis was rejected if the $p$-value was less than 0.05 . Statistical calculations were performed in SPSS version 24:00.

\section{Ethical views}

The protocol of this study was approved by the University of Kurdistan Erbil, Iraq, and the research division of the Ministry of Health/Kurdistan Regional Government. Verbal consent was obtained from all participants. The protocol was registered as number 638 on 14/01/2018 within the research division of the Ministry of Health. Approval for publication was obtained from the University of Kurdistan Erbil and the research division of the Ministry of Health/Kurdistan Regional Government.

\section{Results}

The mean age of the participants was 41.62 years and more than two-thirds of them (67.9\%) were males. The male: female ratio was 2.1:1.0. More than half of the physicians worked in the public sector (55.4\%) and the remaining in both the public and private sectors (44.6\%). The majority of physicians worked in the morning shift between 8 am and $2 \mathrm{pm}$ (67.9\%). More than $40 \%$ of the participants were senior house officers as shown in Table 1. 
Table 1. Baseline physician information

\begin{tabular}{|l|c|c|}
\hline \multirow{2}{*}{ Characteristic (n=296) } & Mean & Frequency distribution \\
\cline { 2 - 3 } \multicolumn{1}{|c|}{ Age (range: 22-64 years) } & 41.62 & Standard dev. \\
\hline Gender & Number & Percentage \\
\hline Male & & 67.9 \\
Female & 201 & 32.1 \\
\hline Working sectors & 95 & 55.4 \\
Public & & 44.6 \\
Both public and private sectors & 164 & 67.9 \\
\hline Working shifts & 132 & 3.7 \\
Morning & & 28.4 \\
Night & 201 & \\
Multi-shift & 11 & 21.3 \\
\hline Job levels & 84 & 44.6 \\
Junior house officer & & 2.0 \\
Senior house officer & 63 & 26.7 \\
General practitioner & 132 & 5.4 \\
Specialist & 6 & \\
Consultant & 79 & \\
\hline
\end{tabular}

\section{Management support}

The physicians reported that hospital management supports the EHR project. They reported that the EHR project is important to top management (87.5\%) and the project will be introduced to them effectively (64.3\%). In addition, they believed that the management will do an effective job during EHR implementation (73.2\%), includes them in the EHR implementation process (59.0\%), and provides the training they need to use the EHR system effectively (62.5\%). They reported that management expects them to use the EHR, but a low percentage of the physicians reported that they will have easy access to resources to help them use it (48.2\%) (Table 2).

Table 2. Physician attitudes towards adopting or implementing Electronic Health Records (EHR) in the Kurdistan Region in Iraq

\begin{tabular}{|l|c|c|c|}
\hline \multicolumn{1}{|c|}{ Dimensions and contents (n=296) } & $\begin{array}{c}\text { Strongly } \\
\text { agree/agree }\end{array}$ & Neutral & $\begin{array}{c}\text { Strongly } \\
\text { disagree/ } \\
\text { disagree }\end{array}$ \\
\hline Management support & $259(87.5)$ & $37(12.5)$ & $0(0)$ \\
EHR project is important to top management & $190(64.3)$ & $90(30.4)$ & $16(5.4)$ \\
EHR project will be introduced to me effectively & $217(73.2)$ & $53(17.9)$ & $26(8.9)$ \\
Management will do an effective job during EHR implementation & $175(59)$ & $100(33.9)$ & $21(7.2)$ \\
Management will involve me in EHR implementation & $185(62.5)$ & $106(35.7)$ & $5(1.8)$ \\
Management will provide training that I need to use EHR effectively & $143(48.2)$ & $111(37.5)$ & $42(14.3)$ \\
I will have easy access to resources to help me use EHR & $196(66.07)$ & $74(25)$ & $100(33.93)$ \\
Management expects me to use EHR & $206(69.6)$ & $63(21.4)$ & $26(8.9)$ \\
\hline Physician involvement & $217(73.2)$ & $69(23.2)$ & $11(3.6)$ \\
My involvement during EHR implementation is a must & $238(80.4)$ & $58(19.6)$ & $0(0)$ \\
My involvement during EHR implementation will be effective & $196(66.1)$ & $100(33.9)$ & $0(0)$ \\
My involvement during EHR implementation will make EHR more & & \\
useful to me & $238(80.4)$ & $58(19.6)$ & $0(0)$ \\
My involvement during implementation will make EHR easier to be & & \\
used & & \\
Overall, my involvement will positively affect my attitude & & \\
\hline
\end{tabular}




\begin{tabular}{|c|c|c|c|}
\hline $\begin{array}{l}\text { Adequate training } \\
\text { Training will be adequate } \\
\text { I will receive training I need to understand/use EHR } \\
\text { Training will make EHR more useful to me } \\
\text { Training will make EHR easier for me to use }\end{array}$ & $\begin{array}{l}206(69.7) \\
206(69.7) \\
201(67.8) \\
185(62.5)\end{array}$ & $\begin{array}{c}74(25) \\
74(25) \\
85(28.6) \\
100(33.9)\end{array}$ & $\begin{array}{l}16(5.4) \\
16(5.4) \\
11(3.6) \\
11(3.6)\end{array}$ \\
\hline $\begin{array}{l}\text { Physician autonomy* } \\
\text { *EHR will increase hospital administration's control } \\
\text { *EHR will increase my hospital ability to control/monitor physician's } \\
\text { clinical practices } \\
\text { *EHR may threaten physician's privacy } \\
\text { *EHR may result in legal/ethical problems for physician } \\
\text { *EHR may limit physician's autonomy } \\
\text { Overall, EHR may negatively affect physician's attitude due to } \\
\text { increased control/monitoring of clinical practices } \\
\text { Overall, EHR may negatively affect physician's attitude due to security, } \\
\text { legal, ethical concerns }\end{array}$ & $\begin{array}{l}122(41.1) \\
90(30.4) \\
153(51.8) \\
164(55.4)\end{array}$ & $\begin{array}{c}69(23.2) \\
53(17.9) \\
116(39.3) \\
148(50) \\
106(35.7) \\
74(25) \\
90(30.4)\end{array}$ & $\begin{array}{c}5(1.8) \\
5(1.8) \\
58(19.7) \\
58(19.7) \\
37(12.5) \\
58(19.6) \\
58(19.7)\end{array}$ \\
\hline $\begin{array}{l}\text { Doctor-patient relationship* } \\
\text { *EHR may diminish patient's confidence in physician } \\
\text { *EHR may threaten physician's credibility with patients } \\
\text { *EHR will likely decrease patient satisfaction } \\
\text { *Overall, EHR will likely interfere with doctor-patient interaction }\end{array}$ & $\begin{array}{l}111(37.5) \\
153(51.8) \\
122(41.1) \\
164(55.4)\end{array}$ & $\begin{array}{l}95(32.1) \\
79(26.8) \\
90(30.4) \\
85(28.6) \\
\end{array}$ & $\begin{array}{l}90(30.3) \\
63(21.4) \\
85(28.6) \\
48(16.1)\end{array}$ \\
\hline $\begin{array}{l}\text { Perceived ease of use } \\
\text { My interaction with EHR will be user-friendly } \\
\text { Learning to use EHR will be easy for me } \\
\text { I expect to become skilled using EHR } \\
\text { Overall, I expect EHR will be easy for physicians to use }\end{array}$ & $\begin{array}{l}206(69.6) \\
217(73.2) \\
185(62.5) \\
190(64.3) \\
\end{array}$ & $\begin{array}{c}90(30.4) \\
74(25) \\
95(32.1) \\
95(32.1) \\
\end{array}$ & $\begin{array}{c}0(0) \\
5(1.8) \\
16(5.4) \\
11(3.6) \\
\end{array}$ \\
\hline $\begin{array}{l}\text { Perceived usefulness } \\
\text { EHR will improve the quality of my work } \\
\text { EHR will give me greater control over my work schedule } \\
\text { EHR will allow me to accomplish tasks more quickly } \\
\text { EHR will allow me to accomplish more work } \\
\text { EHR will enhance my overall effectiveness in my job } \\
\text { EHR will make my job easier to perform } \\
\text { Overall, EHR should be a useful tool for practicing }\end{array}$ & $\begin{array}{l}227(76.8) \\
249(84) \\
211(71.4) \\
211(71.4) \\
211(71.4) \\
227(76.8) \\
190(64.3) \\
\end{array}$ & $\begin{array}{c}63(21.4) \\
32(10.7) \\
74(25) \\
53(17.9) \\
74(25) \\
48(16.1) \\
100(33.9)\end{array}$ & $\begin{array}{l}5(1.8) \\
16(5.4) \\
11(3.6) \\
32(10.7) \\
11(3.6) \\
21(7.1) \\
5(1.8)\end{array}$ \\
\hline $\begin{array}{l}\text { Attitude about EHR usage } \\
\text { EHR will support physicians in providing better care } \\
\text { I will encourage EHR among my colleagues } \\
\text { I need the EHR to provide effective patient care } \\
\text { I am not satisfied with using paper-based patient records } \\
\text { All physicians should learn to use the EHR effectively } \\
\text { Overall, my attitude about EHR usage will be positive }\end{array}$ & $\begin{array}{c}233(78.6) \\
206(69.6) \\
147(49.6) \\
148(50) \\
243(82.2) \\
227(76.6)\end{array}$ & $\begin{array}{c}48(16.1) \\
79(26.8) \\
79(26.8) \\
127(42.9) \\
37(12.5) \\
53(17.9) \\
\end{array}$ & $\begin{array}{l}16(5.4) \\
11(3.6) \\
11(3.6) \\
21(7.2) \\
16(5.4) \\
16(5.4)\end{array}$ \\
\hline
\end{tabular}

Notes: * for the items reversely scored in the questionnaire as they present negative perspectives.

\section{Physician involvement}

The physicians reported that their involvement during EHR implementation is a must (69.6\%), that it will be effective (73.2\%), and that it will make EHR more useful to them (80.4\%). In addition, the physicians reported that their involvement during implementation will make EHR easier to be used (66.1\%) and overall, will positively affect their attitude (80.4\%).

\section{Adequate training}

The physicians reported that the training they will receive for the EHR project will be adequate (69.7\%). Additionally, they will understand how to use the EHR system through the training they will receive (69.7\%). They reported that the training they receive will be useful $(67.8 \%)$ and easy $(62.5 \%)$. 


\section{Physician autonomy}

The physicians had concerns about their autonomy upon implementing the EHR system in public hospitals. They reported that the EHR will increase the control of the hospital administration (75.0\%), the hospital's ability to control/monitor clinical practices (80.4\%), and may threaten physician privacy (41.4\%). The physicians reported that EHR may negatively affect physician attitudes due to increased control/monitoring of clinical practices (55.4\%), or due to security, legal, and ethical concerns (50.0\%) and limit physician autonomy (51.8\%). Only a low percentage of physicians reported that it may result in legal/ethical problems for them (30.4\%).

\section{Doctor-patient relationship}

A considerable percentage of physicians reported that an EHR system may diminish patient confidence in physicians (37.5\%), may threaten physician credibility with patients (51.8\%), will likely interfere with doctorpatient interactions (55.4\%), and decrease patient satisfaction (41.1\%).

\section{Perceived ease of use}

Regarding perceived ease of use, the physicians reported that their interaction with EHR will be user-friendly $(69.6 \%)$ and that learning to use EHR will be easy for them (73.2\%). They expect that the EHR system will be easy for the physician to use (64.3\%) and become skilled at using it (62.5\%).

\section{Perceived usefulness}

The physicians reported that the EHR will improve the quality of their work (76.8\%), give them greater control over their schedule (84.0\%), allow them to accomplish tasks more quickly (71.4\%), and allow them to accomplish more work (71.4\%). In addition, it will enhance their overall effectiveness in their job (71.4\%) and will make their job easier to perform (76.8\%). They believed that overall EHR is a useful tool in medical practice $(64.3 \%)$.

\section{Attitude around EHR usage}

The physicians reported that EHR will support physicians in providing better care (78.6\%) and will encourage the use of EHR among their colleagues (69.6\%). Close to half of the physicians reported that they need an EHR system to provide effective patient care (49.6\%) and that they are not satisfied using paper-based patient records (50.0\%). Moreover, they reported that all physicians should learn to use EHR effectively (82.2\%) and overall had a positive attitude about the EHR (76.6\%) (Table 2).

In the linear regression model, physician autonomy was considered a dependent variable and other physician attitudes along with baseline information as independent variables. The analysis showed that physicians felt their autonomy is limited or that their privacy is threatened in regards to the patient-doctor relationship $(p<0.001)$. Autonomy was significantly limited among male doctors $(p=0.048)$, those working in both public and private sectors $(p=0.001)$, and consultants $(p=0.013)$ (Table 3$)$.

Table 3. Predictors of physician authonomy as a barrier in EHR implementation taking into account the doctor-patient relationship

\begin{tabular}{|c|c|c|c|c|c|}
\hline \multicolumn{6}{|c|}{ Dependent variable: physician autonomy } \\
\hline \multirow{2}{*}{ Predictors $(n=296)$} & Standardized & \multirow{2}{*}{$\mathbf{t}$} & \multirow{2}{*}{ Sig. } & \multicolumn{2}{|c|}{ 95\% CI for B } \\
\hline & Beta & & & Lower Bound & Upper Bound \\
\hline Management support & -0.123 & -0.696 & 0.490 & -0.477 & 0.232 \\
\hline Physician involvement & 0.256 & 1.819 & 0.076 & -0.034 & 0.655 \\
\hline Adequate training & 0.215 & 1.544 & 0.130 & -0.065 & 0.492 \\
\hline Doctor-patient relationship & 0.655 & 6.072 & $<0.001$ & 0.281 & 0.560 \\
\hline Perceived ease of use & 0.088 & 0.455 & 0.651 & -0.294 & 0.466 \\
\hline Perceived usefulness & -0.202 & -0.962 & 0.342 & -0.577 & 0.205 \\
\hline
\end{tabular}




\begin{tabular}{|l|c|c|c|c|c|}
\hline Attitude about the usage & -0.225 & -1.302 & 0.200 & -0.638 & 0.137 \\
\hline Physician age & 0.168 & 0.931 & 0.357 & -0.014 & 0.037 \\
\hline Gender & 0.260 & 2.039 & $\mathbf{0 . 0 4 8}$ & 0.004 & 0.648 \\
\hline Education & 0.585 & 2.606 & $\mathbf{0 . 0 1 3}$ & 0.062 & 0.489 \\
\hline Working sectors & -0.609 & -3.615 & $\mathbf{0 . 0 0 1}$ & -0.558 & -0.158 \\
\hline Working shift & 0.202 & 1.814 & 0.077 & -0.010 & 0.184 \\
\hline
\end{tabular}

Notes: Linear regression was performed for statistical analysis. The numbers in bold are the predictors.

The detailed analysis that included items pertaining to the doctor-patient relationship in the linear regression showed that doctors felt their autonomy would be limited due to the interference of EHR in doctor-patient interactions $(p=0.003)$ (Table 4$)$.

Table 4. Predictors of physician autonomy as a barrier in EHR implementation with inclusion of doctor-patient relationship items

\begin{tabular}{|c|c|c|c|c|c|}
\hline \multicolumn{6}{|c|}{ Dependent variable: physician autonomy } \\
\hline \multirow{2}{*}{ Predictors $(n=296)$} & \multirow{2}{*}{$\begin{array}{c}\begin{array}{c}\text { Standardized } \\
\text { Coefficients }\end{array} \\
\text { Beta }\end{array}$} & \multirow{2}{*}{$\mathbf{t}$} & \multirow{2}{*}{$p$-value } & \multicolumn{2}{|c|}{$95 \%$ CI for B } \\
\hline & & & & $\begin{array}{l}\text { Lower } \\
\text { Bound }\end{array}$ & $\begin{array}{l}\text { Upper } \\
\text { Bound }\end{array}$ \\
\hline Management support & -0.045 & -0.247 & 0.806 & -0.412 & 0.322 \\
\hline Physician involvement & 0.230 & 1.591 & 0.119 & -0.076 & 0.636 \\
\hline Adequate training & 0.210 & 1.486 & 0.145 & -0.075 & 0.491 \\
\hline Perceived ease of use & 0.134 & 0.691 & 0.494 & -0.253 & 0.516 \\
\hline Perceived usefulness & -0.279 & -1.293 & 0.203 & -0.660 & 0.145 \\
\hline Attitude about the usage & -0.236 & -1.370 & 0.178 & -0.651 & 0.125 \\
\hline Physician age & 0.194 & 1.067 & 0.292 & -0.012 & 0.039 \\
\hline Gender & 0.227 & 1.757 & 0.087 & -0.043 & 0.612 \\
\hline Education & 0.529 & 2.338 & 0.024 & 0.034 & 0.465 \\
\hline Working sectors & -0.611 & -3.554 & 0.001 & -0.563 & -0.155 \\
\hline Working shift & 0.210 & 1.848 & 0.072 & -0.008 & 0.189 \\
\hline EHR may diminish patient confidence in physicians & 0.087 & 0.515 & 0.609 & -0.125 & 0.211 \\
\hline $\begin{array}{l}\text { EHR may threaten physician credibility with } \\
\text { patients }\end{array}$ & 0.186 & 1.029 & 0.310 & -0.096 & 0.295 \\
\hline EHR will likely decrease patient satisfaction & 0.153 & 1.107 & 0.275 & -0.068 & 0.233 \\
\hline $\begin{array}{l}\text { Overall, EHR will likely interfere with doctor- } \\
\text { patient interactions }\end{array}$ & 0.391 & 3.179 & 0.003 & 0.085 & 0.381 \\
\hline
\end{tabular}

Notes: Linear regression analysis was performed. The numbers in bold are the predictors.

The doctor-patient relationship (a barrier in EHR implementation) was considered a dependent variable, and doctor attitudes towards EHR implementation along with baseline information were the predictors in the regression analysis. Results of the analysis showed that doctors had concerns about their relationship with patients with respect to their autonomy $(p<0.001)$. The male doctors have a worse relationship with patients compared to females $(p=0.012)$, specialists $(p=0.005)$, and those physicians work in both sectors $(p=0.002)$ (Table 5). 
Table 5. Predictors of doctor-patient relationship in implementation of EHR considering overall physician autonomy

\begin{tabular}{|c|c|c|c|c|c|}
\hline \multicolumn{6}{|c|}{ Dependent variable: doctor-patient relationship } \\
\hline \multirow{2}{*}{ Predictors $(n=296)$} & \multirow{2}{*}{$\begin{array}{c}\begin{array}{c}\text { Standardized } \\
\text { Coefficients }\end{array} \\
\text { Beta } \\
\end{array}$} & \multirow{2}{*}{$\mathbf{t}$} & \multirow{2}{*}{$p$-value } & \multicolumn{2}{|c|}{$95.0 \%$ CI for B } \\
\hline & & & & Lower Bound & Upper Bound \\
\hline Management support & -0.158 & -0.867 & 0.391 & -0.817 & 0.326 \\
\hline Physician involvement & -0.210 & -1.422 & 0.162 & -0.963 & 0.167 \\
\hline Adequate training & 0.023 & 0.152 & 0.880 & -0.427 & 0.497 \\
\hline Physician autonomy & 0.705 & 6.072 & 0.000 & 0.733 & 1.462 \\
\hline Perceived ease of use & 0.264 & 1.349 & 0.184 & -0.200 & 1.006 \\
\hline Perceived usefulness & -0.144 & -0.657 & 0.514 & -0.842 & 0.428 \\
\hline Attitude about the usage & 0.332 & 1.892 & 0.065 & -0.038 & 1.189 \\
\hline Physician age & 0.039 & 0.205 & 0.838 & -0.037 & 0.046 \\
\hline Gender & -0.337 & -2.621 & 0.012 & -1.164 & -0.152 \\
\hline Education & -0.669 & -2.924 & 0.005 & -0.831 & -0.152 \\
\hline Working sectors & 0.597 & 3.359 & 0.002 & 0.219 & 0.875 \\
\hline Working shift & -0.244 & -2.136 & 0.038 & -0.317 & -0.009 \\
\hline
\end{tabular}

Notes: Linear regression analysis was performed. The numbers in bold are the predictors.

The doctor-patient relationship was considered a dependent variable and the autonomy items as independent variables in adjustment with baseline information for detailed analysis. The analysis showed that the concerns of doctors towards their relationship with patients were owing to their concerns towards threatening privacy $(p=0.008)$ and limiting physician autonomy $(p=0.003)$. This analysis showed that the doctors working in the morning shift had a worse relationship with their patients $(p=0.023)$ (Table 6).

Table 6. Predictors of doctor-patient relationship in implementation of EHR with inclusion of physician autonomy items

\begin{tabular}{|c|c|c|c|c|c|}
\hline \multicolumn{6}{|c|}{ Dependent variable: doctor-patient relationship } \\
\hline \multirow{2}{*}{ Predictors $(n=296)$} & \multirow{2}{*}{$\begin{array}{c}\begin{array}{c}\text { Standardized } \\
\text { Coefficients }\end{array} \\
\text { Beta }\end{array}$} & \multirow{2}{*}{$\mathbf{t}$} & \multirow{2}{*}{$p$-value } & \multicolumn{2}{|c|}{$95.0 \%$ CI for B } \\
\hline & & & & $\begin{array}{l}\text { Lower } \\
\text { Bound }\end{array}$ & $\begin{array}{l}\text { Upper } \\
\text { Bound }\end{array}$ \\
\hline Management support & -0.107 & -0.601 & 0.551 & -0.726 & 0.394 \\
\hline Physician involvement & -0.098 & -0.672 & 0.506 & -0.744 & 0.373 \\
\hline Adequate training & -0.017 & -0.121 & 0.904 & -0.477 & 0.423 \\
\hline Perceived ease of use & 0.271 & 1.397 & 0.171 & -0.186 & 1.011 \\
\hline Perceived usefulness & -0.061 & -0.301 & 0.765 & -0.680 & 0.504 \\
\hline Attitude about the usage & 0.254 & 1.372 & 0.178 & -0.210 & 1.090 \\
\hline Physician age & -0.040 & -0.213 & 0.832 & -0.046 & 0.037 \\
\hline Gender & -0.247 & -1.889 & 0.067 & -1.000 & 0.035 \\
\hline Education & -0.579 & -2.452 & 0.019 & -0.777 & -0.074 \\
\hline Working sectors & 0.448 & 2.605 & 0.013 & 0.091 & 0.729 \\
\hline Working shift & -0.254 & -2.368 & 0.023 & -0.315 & -0.025 \\
\hline EHR will increase hospital administration control & -0.018 & -0.128 & 0.899 & -0.371 & 0.327 \\
\hline $\begin{array}{l}\text { EHR will increase my hospital's ability to control/ } \\
\text { monitor physician clinical practices }\end{array}$ & -0.148 & -1.051 & 0.300 & -0.534 & 0.169 \\
\hline EHR may threaten physician privacy & 0.395 & 2.795 & 0.008 & 0.098 & 0.616 \\
\hline $\begin{array}{l}\text { EHR may result in legal/ethical problems for } \\
\text { physicians }\end{array}$ & 0.147 & 1.176 & 0.247 & -.103 & 0.388 \\
\hline EHR may limit physician autonomy & 0.379 & 3.188 & 0.003 & 0.120 & 0.539 \\
\hline
\end{tabular}




\begin{tabular}{|l|c|c|c|c|c|}
\hline $\begin{array}{l}\text { Overall, EHR may negatively affect physician } \\
\text { attitudes due to increased control/monitoring of } \\
\text { clinical practices }\end{array}$ & 0.038 & 0.273 & 0.786 & -0.194 & 0.254 \\
\hline $\begin{array}{l}\text { Overall, EHR may negatively affect physician } \\
\text { attitudes due to security, legal, ethical concerns }\end{array}$ & 0.054 & 0.404 & 0.689 & -0.191 & 0.287 \\
\hline
\end{tabular}

Notes: Linear regression analysis was performed. The numbers in bold are the predictors.

\section{Discussion}

This study found that physicians had positive attitudes towards most aspects of EHR implementation in public hospitals in Iraqi Kurdistan. However, they also slightly agreed that their autonomy may be limited and overall monitoring of clinician practices will increase owing to the system's interference in doctor-patient interactions, which could threaten physician privacy and limit physician autonomy. This could also diminish patient confidence in doctors, resulting in a decrease in patient satisfaction.

Khalifa et al. [20] reported six main categories of barriers in the implementation of EHR in Saudi Arabia, which included a) human barriers associated with beliefs, behaviors, and attitudes; b) professional barriers related to the nature of medical professions; c) technical barriers related to computers and IT; d) organizational barriers related to hospital management; e) financial barriers, and f) legal and regulatory barriers. Resistance has been reported when a system changes from traditional paper medical records to electronic medical records in both developed and developing countries [9,30].

The EHR system has not been planned and implemented in Iraqi Kurdistan and Iraq. The optimistic finding in this study was that most of the participants did not resist the EHR system. There is a large gap between planning for the implementation of EHR in hospitals and the success of implementation in developing countries [31]. Physicians showed high readiness to be involved in the implementation of EHR in this region, which is a strong positive indicator for health care organizations to consider.

El-Hassan et al. reported that based on the Middle East Electronic Medical Record Adoption Model (EMRAM), the number of hospitals that participated in EHRs had increased from 23 to 33 between 2011 and 2016. EMRAM is ranked based on eight stages that cover the spectrum of EHR implementation "from stage zero (a paper-based environment) to stage seven (an environment that is paper-free)." Stage two means clinical data repository, controlled medical vocabulary, and clinical decision support may be document imaging and health information exchange capable. Stage five means there is a full complement of radiology-picture archiving and that an electronic communication system displaces all film-based images. El-Hassan and colleagues found that 20 out of the 33 hospitals were at stage two or lower and 10 were at stage five [32].

In Saudi Arabia, the implementation of an EHR system is underway in many hospitals and organizations [33]. The Hakeem project in Jordan attempted to integrate various types of health information systems, including administrative, radiology, laboratory, pharmacy, computerized physician order, and clinical documentation systems [34]. Turkey's NHIS (NHIS-T) came into operation in 2009 and $99 \%$ of public hospitals and $71 \%$ of private and university hospitals are integrated into the system. Numerous positives were reported about the potential of EHR to improve clinical productivity, patient safety, and care quality [35].

Potential disruption of the patient-doctor relationship associated with EHR implementation has been reported in other studies [14]. Physicians reported that their eyes mostly look for menus and buttons on the computer screen, precluding them from establishing a more efficient relationship with the patient. Therefore, sometimes, they resort to not using the system [36]. A possible reason for this could be that physicians may feel they're spending considerable time entering data into the computer rather than interacting with patients. Therefore, the clients do not see the EHR as an opportunity for overall improvement in patient-doctor communication [14]. Linder et al. reported that in their survey of 255 doctors and advanced practice providers, practitioners feel they lose eye contact with patients when they are in front of a computer [37].

More than $40 \%$ of subjects who participated in this study reported that EHR threatens physician privacy. They believe that EHR negatively affects physician attitudes due to increased control/monitoring of clinical practices by hospital administration (55.4\%). Physicians are sensitive about their clinical practices, which is why they consider EHR systems a risk to their privacy and security, resulting in them using traditional paperbased systems rather than electronic methods [17]. Other investigators reported similar concerns of physician confidentiality, security, and privacy [38-40].

Security is often easier with paper-based medical documents compared with electronic record keeping. However, common issues with paper records include illegibility, file loss, mistakes in filling out the medical 
records (e.g. failure to complete obligatory fields, missing or unrelated data, etc.). In contrast, electronic medical files are dynamic and can be attacked in different ways, with security risks such as hacking, destruction of computer hardware, or overcoming software-based security. The security aspects of paper-based systems are simple and summarized as a sequence of events. In contrast, the data of electronic records are not bound to a particular physical carrier. The data can be easily copied, submitted over long distances, and lost or erased [17].

It is highly recommended to take into consideration many of these barriers, which have also been noted in studies from other countries. Many of these barriers have been responsible for the non-adoption of even basic EHR systems in one-fourth of hospitals in the USA despite incentives provided by the federal government [41]. Moreover, we need to understand the barriers to EHR systems to facilitate the adoption and implementation process. In a study conducted in Massachussetts, Simon et al. [42] reported that 455 physicians had access to EHRs and of those, only 23\% used them due to barriers such as financial challenges, lack of capital resources in EHR investment, system complexities, physician cooperation, lack of sufficient IT staff or technical support, illegal tampering concerns, safety concerns, lack of high-speed connectivity, lack of interoperability, and workflow challenges. Similarly, implementing challenges, perceived usefulness by medical staff, busyness impact, integration systems, and system limitations [7,43,44], and organizational culture [45].

We do not expect that effective implementation of EHR systems will be a concern to physicians overall as they reported generally positive attitudes on the potential impacts of electronic records in improving quality of care [41]. Although this study demonstrated some of the same barriers reported in other countries, such as Saudi Arabia and Canada, other barriers may appear when the systems are implemented. Therefore, the context of these factors in Kurdistan hospitals must be understood to enhance EHR adoption because the rate of implementation remains low and meets resistance from healthcare professionals [20], with resistance being common in both the developing and developed world [9].

Most healthcare providers and clinical practitioners are aware of the change from paper-based systems to electronic systems. Hence, time is required to help medical practitioners change their perceptions towards electronic systems [20]. The Ministry of Health, as the major government agency responsible for preventive, curative, and rehabilitation health care services in Iraqi Kurdistan, needs to establish proper strategies prior to implementation.

The resistance of physicians towards EHR systems is attributable to several factors, but not limited to, 1) EHR system failure; 2) limited computer literacy among some physicians; 3) productivity concerns; 4) patient satisfaction, and 5) non-reliable technology [46].

We anticipate more negative attitudes among governmental arms when implementing EHR systems in private medical practices. We suggest that legislation must be the first stage of implementation and that the systems must first be introduced in public hospitals. Several of the physicians in this study work in both the public and private sectors. System implementation in public hospitals can help medical practitioners become familiar with it before implementation in their clinics in the private sector. To obtain a complete picture of the barriers and facilitators involved in the future implementation of EHR systems in Iraqi Kurdistan, medical practitioners such as nurses and lab technicians must also be included in any subsequent studies and eventual implementation.

\section{Limitations of the study}

1. Construct validity. The scale was specifically designed for clinical settings based on the Technology Acceptance Model (TAM). Additionally, the items of each indicator were designed based on previous valid theories, since Diffusion of Innovations (DOI) theory and TAM were used as a framework to develop the research questions.

2. External validity. The participants in this investigation were selected from four public hospitals that may not be representative of all clinical settings and medical specialists in this region and the rest of the country. However, a broad range of medical specialties in multi-specialty hospitals across the urban areas were invited to participate in the study.

3. Internal validity. Language was not an issue in this study since the official teaching language in medicine in this region is English. The author that recruited the physicians explained the required information and the study purposes in the same manner to all participants. The overall internal reliability of the scale was 0.922 (Cronbach's Alpha). 


\section{Conclusions}

The findings of this study revealed that physicians believe hospital management will support the implementation of an EHR system; that physicians will be involved in the process, management will present sufficient and effective training sessions; the system will be user-friendly and easy; the system is useful and improves care quality; and it improves overall work schedules.

However, physicians have concerns about autonomy because they believe the system interferes with doctorpatient interactions. They feel the system could erode the patient-doctor relationship because of threats to physician privacy and limiting physician autonomy.

\section{Disclosures and acknowledgements}

The authors declare no potential conflicts of interest with respect to the research, authorship, and/or publication of this article. This work was funded by the authors.

The authors would like to thank the Ministry of Health/KRG for facilitating the study and the physicians who participated in the study.

\section{References:}

1. Ajami S, Bagheri-Tadi T. Barriers for adopting electronic health records (EHRs) by physicians. Acta Informatica Medica. 2013; 21(2): 129. https://doi.org/10.5455/aim.2013.21.129-134

2. Grinspan Z, Banerjee S, Kaushal R, Kern L. Physician specialty and variations in adoption of electronic health records. Applied Clinical Informatics. 2013; 4(02): 225-240. https://doi.org/10.4338/ACI-2013-02-RA-0015

3. Jha AK, DesRoches CM, Campbell EG, Donelan K, Rao SR, Ferris TG, et al. Use of electronic health records in US hospitals. New England Journal of Medicine. 2009; 360(16): 1628-1638. https://doi.org/10.1056/ NEJMsa0900592

4. Castillo VH, Martínez-García AI, Pulido J. A knowledge-based taxonomy of critical factors for adopting electronic health record systems by physicians: a systematic literature review. BMC Medical Informatics \& Decision Making. 2010; 10(1): 60. https://doi.org/10.1186/1472-6947-10-60

5. Randeree E. Exploring physician adoption of EMRs: a multi-case analysis. Journal of Medical Systems. 2007; 31(6): 489-496. https://doi.org/10.1007/s10916-007-9089-5

6. Bowens FM, Frye PA, Jones WA. Health information technology: integration of clinical workflow into meaningful use of electronic health records. Perspectives in Health Information Management/AHIMA, American Health Information Management Association. 2010; 7(Fall).

7. Kruse CS, Kristof C, Jones B, Mitchell E, Martinez A. Barriers to electronic health record adoption: a systematic literature review. Journal of Medical Systems. 2016; 40(12): 252. https://doi.org/10.1007/ s10916-016-0628-9

8. Adler-Milstein J, Holmgren AJ, Kralovec P, Worzala C, Searcy T, Patel V. Electronic health record adoption in US hospitals: the emergence of a digital "advanced use" divide. Journal of the American Medical Informatics Association. 2017; 24(6): 1142-1148. https://doi.org/10.1093/jamia/ocx080

9. Borycki E, Joe RS, Armstrong B, Bellwood P, Campbell R. Educating health professionals about the electronic health record (EHR): removing the barriers to adoption. Knowledge Management \& E-Learning. 2011; 3(1): 51. https://doi.org/10.34105/j.kmel.2011.03.006

10. Miller RH, Sim I. Physicians' use of electronic medical records: barriers and solutions. Health Affairs. 2004; 23(2): 116-126. https://doi.org/10.1377/hlthaff.23.2.116

11. Pelland KD, Baier RR, Gardner RL. "It's like texting at the dinner table": A qualitative analysis of the impact of electronic health records on patient-physician interaction in hospitals. Journal of Innovation in Health Informatics. 2017; 24(2): 216-223. https://doi.org/10.14236/jhi.v24i2.894

12. Shachak A, Reis S. The impact of electronic medical records on patient-doctor communication during consultation: a narrative literature review. Journal of Evaluation in Clinical Practice. 2009; 15(4): 641-649. https://doi.org/10.1111/j.1365-2753.2008.01065.X

13. Park SY, Lee SY, Chen Y. The effects of EMR deployment on doctors' work practices: a qualitative study in the emergency department of a teaching hospital. International Journal of Medical Informatics. 2012; 81(3): 204-217. https://doi.org/10.1016/j.ijmedinf.2011.12.001

14. Ajami S, Ketabi S, Saghaeiannejad S, Heidari A. Requirements and areas associated with readiness assessment of electronic health records implementation. Journal of Health Administration. 2011; 14(46). 
15. Yehualashet DE, Seboka BT, Tesfa GA, Demeke AD, Amede ES. Barriers to the adoption of electronic medical record system in Ethiopia: a systematic review. Journal of Multidisciplinary Healthcare. 2021; $14: 2597$. https://doi.org/10.2147/JMDH.S327539

16. Heeks R. Health information systems: failure, success and improvisation. International Journal of Medical Informatics. 2006; 75(2): 125-137. https://doi.org/10.1016/j.ijmedinf.2005.07.024

17. Susło R, Trnka J, Drobnik J. Current threats to medical data security in family doctors' practices. Family Medicine \& Primary Care Review. 2017; 3: 313-318. https://doi.org/10.5114/fmpcr.2017.69297

18. Bates DW. Physicians and ambulatory electronic health records. Health Affairs. 2005; 24(5): 1180-1189. https://doi.org/10.1377/hlthaff.24.5.1180

19. Kaplan B, Harris-Salamone KD. Health IT success and failure: recommendations from literature and an AMIA workshop. Journal of the American Medical Informatics Association. 2009; 16(3): 291-299. https:// doi.org/10.1197/jamia.M2997

20. Khalifa M. Barriers to health information systems and electronic medical records implementation. A field study of Saudi Arabian hospitals. Procedia Computer Science. 2013; 21: 335-342. https://doi.org/10.1016/j. procs.2013.09.044

21. Shabila NP, Al-Tawil NG, Al-Hadithi TS, Sondorp E, Vaughan K. Iraqi primary care system in Kurdistan region: providers' perspectives on problems and opportunities for improvement. BMC International Health \& Human Rights. 2012; 12(1): 21. https://doi.org/10.1186/1472-698X-12-21

22. Morton ME. Use and acceptance of an electronic health record: factors affecting physician attitudes [dissertation]. Philadelphia: Drexel University; 2008.

23. Sullivan GM, Artino Jr AR. Analyzing and interpreting data from Likert-type scales. Journal of Graduate Medical Education. 2013; 5(4): 541-542. https://doi.org/10.4300/JGME-5-4-18

24. Davis FD, Bagozzi RP, Warshaw PR. User acceptance of computer technology: a comparison of two theoretical models. Management Science. 1989; 35(8): 982-1003. https://doi.org/10.1287/mnsc.35.8.982

25. Davis FD. Perceived usefulness, perceived ease of use, and user acceptance of information technology. MIS Quarterly. 1989; 319-340. https://doi.org/10.2307/249008

26. Azjen I. Understanding attitudes and predicting social behavior. Englewood Cliffs, N.J. : Prentice-Hall; 1980.

27. Fishbein M, Ajzen I. Belief, attitude, intention, and behavior: An introduction to theory and research. Reading, MA: Addison-Wesley; 1977.

28. Legris P, Ingham J, Collerette P. Why do people use information technology? A critical review of the technology acceptance model. Information \& Management. 2003; 40(3): 191-204. https://doi.org/10.1016/ S0378-7206(01)00143-4

29. Venkatesh V, Davis FD. A model of the antecedents of perceived ease of use: development and test. Decision Sciences. 1996; 27(3): 451-481. https://doi.org/10.1111/j.1540-5915.1996.tb01822.x

30. Boonstra A, Broekhuis M. Barriers to the acceptance of electronic medical records by physicians from systematic review to taxonomy and interventions. BMC Health Services Research. 2010; 10(1): 231. https:// doi.org/10.1186/1472-6963-10-231

31. Kalogriopoulos NA, Baran J, Nimunkar AJ, Webster JG. Electronic medical record systems for developing countries. In: Proceedings of the 2009 Annual International Conference of the IEEE Engineering in Medicine and Biology Society; 2009 Sep 3-6; Minneapolis, MN, USA; Piscataway Township: IEEE; 2009. https://doi. org/10.1109/IEMBS.2009.5333561

32. El-Hassan O, Sharif A, Al MR, Blair I. Tracking the implementation of electronic medical records in Dubai, United Arab Emirates, using an adoption benchmarking tool. Studies in Health Technology and Informatics. 2017; 245: 64-68.

33. Alsahafi YA. Studies of EHR implementation and operation in different countries with particular reference to Saudi Arabia [master's thesis]. Auckland: Massey University; 2012.

34. Dua'A N, Othman M, Yahya H. Implementation of an EHR system (Hakeem) in Jordan: challenges and recommendations for governance. HIM-Interchange Journal. 2013; 3(3): 10-12.

35. O’Donnell A, Kaner E, Shaw C, Haighton C. Primary care physicians' attitudes to the adoption of electronic medical records: a systematic review and evidence synthesis using the clinical adoption framework. BMC Medical Informatics and Decision Making. 2018; 18(1): 101. https://doi.org/10.1186/s12911-018-0703-x

36. Loomis GA, Ries JS, Saywell Jr RM, Thakker NR. If electronic medical records are so great, why aren't family physicians using them?. Journal of Family Practice. 2002; 51(7): 636-642.

37. Linder JA, Schnipper JL, Tsurikova R, Melnikas AJ, Volk LA, Middleton B., editors. Barriers to electronic health record use during patient visits. Proceedings of AMIA Annual Symposium; 2006 Nov 11-15; Washington; USA; Bethesda: American Medical Informatics Association; 2006. p. 499-503 
38. Ludwick D, Doucette J. Primary care physicians' experience with electronic medical records: barriers to implementation in a fee-for-service environment. International Journal of Telemedicine and Applications. 2009; 2009: 2. https://doi.org/10.1155/2009/853524

39. Jha AK, Bates DW, Jenter C, Orav EJ, Zheng J, Cleary P, et al. Electronic health records: use, barriers and satisfaction among physicians who care for black and Hispanic patients. Journal of Evaluation in Clinical Practice. 2009; 15(1): 158-163. https://doi.org/10.1111/j.1365-2753.2008.00975.x

40. Al Farsi M, West DJ. Use of electronic medical records in Oman and physician satisfaction. Journal of Medical Systems. 2006; 30(1): 17-22. https://doi.org/10.1007/s10916-006-7399-7

41. Charles D, Gabriel M, Furukawa MF. Adoption of electronic health record systems among US non-federal acute care hospitals: 2008-2012. ONC Data Brief. 2013; 9: 1-9.

42. Simon SR, Kaushal R, Cleary PD, Jenter CA, Volk LA, Poon EG, et al. Correlates of electronic health record adoption in office practices: a statewide survey. Journal of the American Medical Informatics Association. 2007; 14(1): 110-117. https://doi.org/10.1197/jamia.M2187

43. Kruse CS, Mileski M, Alaytsev V, Carol E, Williams A. Adoption factors associated with electronic health record among long-term care facilities: a systematic review. BMJ Open. 2015; 5(1): e006615. https://doi. org/10.1136/bmjopen-2014-006615

44. Beasley S, Girard J. Office-based physician EHR adoption and use in southern US states. In: Proceedings of SAIS 2016; 2016 Oct 22-24; Atlanta; USA; Atlanta: SAIS; 2016.

45. Ajami S, Ketabi S, Isfahani SS, Heidari A. Readiness assessment of electronic health records implementation. Acta Informatica Medica. 2011; 19(4): 224. https://doi.org/10.5455/aim.2011.19.224-227

46. Hier DB. Physician buy-in for an EMR. Healthcare Informatics: the Business Magazine for Information and Communication Systems. 2002; 19(10): 37. 